\title{
Performance of Health Service on Home Care and Marine Ambulance Telemedicine in The City of Makassar
}

\author{
Hargitayanti Hargitayanti*, Muh. Akmal, Hasniati Hasniati \\ Universitas Hasanuddin, Makassar, Indonesia \\ *Corresponding author: hargitayantisaleh@gmail.com
}

\begin{abstract}
This study aimed to measure the performance of home care-based health services and marine ambulance telemedicine in Makassar City. Public health has a vital role in improving the quality of human resources, poverty alleviation, and economic development. The Human Development Index puts health as one of the primary measurement components besides education and income. With the weakening of health services based on Home Care and Ambulance Telemedicine Marine, the community feels they do not get adequate services. People expect to get better and more effective health services. Still, they find that health services are getting weaker. This study uses a quantitative descriptive method, using a questionnaire to collect data with 307 respondents based on the Slovin formula. This study indicates that the performance of home care-based health services and marine ambulance telemedicine in Makassar City is still categorized as not good; this is seen from 29.5\%, indicating that the performance of health services is still poor assessment.
\end{abstract}

Keywords: Service Performance, Public Service, Homecare And Telemedicine

\section{INTRODUCTION}

Public health has a vital role in improving the quality of human resources and reducing poverty and economic development. [1] The Human Development Index makes health one of the primary measurement components besides education and income. Therefore, every activity carried out to improve public health is based on the principles of non-discrimination, participation, protection, and sustainability, which are very important for forming Indonesian human resources, increasing the nation's resilience and competitiveness, and national development. [2]

The general state of Indonesia's health is influenced by environmental factors, health services, and behavior. [3] Meanwhile, health services consist of several components, including the availability and quality of health service facilities, medicines and supplies, financing, health personnel, and health management. [4] Basic health service facilities, namely Public health centers supported by Supporting Health Centers and Mobile Health Centers, were established in almost all parts of Indonesia, however equity and affordability of health services are still obstacles. [5]
Indonesia has more than 17,000 islands composed of large and small islands. It has a critical strategic position. It is close to two continents and two oceans and is on international traffic and trade routes. This situation has caused many entrances into Indonesian territory to become a risk factor for spreading diseases and health problems. Indonesia is one of the most populous countries globally, and the population density levels outside of Java and Java are uneven. This situation may cause problems. Health requires comprehensive attention from the government and society.

Programs Home Care And Telemedicine are health services that are carried out remotely, the scope of which is vast, such as providing health services, education, and administrative services. Home Care and Telemedicine have become an essential part of a treatment whose benefits accelerate patient access to referral centers as a form of first aid to patients. [6]

Home Care And Telemedicine Ensure that people who experience health problems can be helped quickly every day. With Home Care and Telemedicine, the people of Makassar City hope to provide fast and appropriate first aid services by picking them up directly at the patient's house. 
Programs are Homecare and telemedicine expected to reduce the patient's anxiety about health services, especially for island communities that are difficult to reach. [7]Programs Homecare and telemedicine are also used to select patients who need special care and patients who can be treated only by visiting the patient's home. ambulance service This marine is specifically for island communities who must be referred and need health services, especially in emergencies. [8]ambulance service This marine is designed with maximum speed and can operate in various conditions, such as strong winds and high waves.[9]

Makassar city government issued Makassar City Regional Regulation Number 7 of 2009 concerning Health Services in Makassar City Article 2, namely "Provision of health services is carried out by the government by the Public Health Center Hospital and its network." So with an ambulance this sea, people in the Barrang Lompo Islands in Makassar City can receive treatment quickly and evenly. As well as in article 3, namely "service recipients are residents of the City and outside the City" then the government does have an obligation to provide health service facilities to the island community. Ambulance This sea is expected to reach every island in Makassar City; an ambulance also hoped that the ocean has a high use value and is right on target. Because of ambulances, this sea is expected to bring access to health services closer to all people in the islands. For example, during bad weather and strong winds.

Performance is the result of work achieved by a person or group, such as the standard of work determined during a specific period guided by norms, producer operational standards, criteria, and functions determined or applicable in the office. The performance is out of the light of the process and results of the work. In other words, performance concerns how the work process takes place and how the results are achieved. The Home Care and Ambulance Telemedicine Marine programs, which were expected to provide first aid to island communities who needed help, did not run effectively.[6] The community found the weakening of health services in Makassar City, Home Care, and Ambulance Telemedicine services Marine Became ineffective when contacted Call Center 112, no one answered. The programs Home Care and Ambulance Telemedicine Marine Operate for 24 hours- nonstop, but in reality, the people who need help do not respond.

With the weakening of health services based on Home Care and Telemedicine Ambulance, the Marinette community feels that they are not getting effective services. People expect to get better and more effective health services; they find them increasingly weak. Due to the lack of human resources, according to a statement from the Makassar City Health Office, health services in Makassar City have become ineffective and the weakening of health services based on Home Care And Ambulance Telemedicine Marine.

The people of Makassar City also received very disappointing health services. When they contacted the Call Center Home Care and Telemedicine 112, the community did not answer. When the congregation reached the health service, they found delays in assisting. There were refusals from various hospitals in Makassar City because they did not have ambulances and guards; other hospitals gave reasons for not having patient pick-up services. Thus, this is not in line with the Makassar City Regulation Number 7 of 2009 concerning Health Services in Makassar City.

Based on the above background, the writer is interested in researching with the title "Performance of health service on home care and marine ambulance telemedicine in the city of Makassar."

\section{RESEARCH METHOD}

In this study, the approach used was descriptive quantitative by questionnaires to predetermined respondents. [10] In this study, researchers describe in detail, depth, and comprehensively related to the Performance of Based Health Services Home Careand Ambulance Telemedicine Marinein Makassar City. To the people of Barring Lompo Island. Through this approach, researchers will analyze in more depth how the programs are Home Care and Ambulance Telemedicine Marinerun, using quantitative methods as benchmarks that make the benchmark for the success or failure of the performance of the health services provided. By involving various individuals, groups, and organizations that can be scientifically justified. The data collection technique used by the author in this study looked at a large number of respondents, namely by distributing questionnaires and conducting a document review. The questionnaire in question is through a list of questions allocated to all respondents. Document review is a study of literature sources, documents, regulations, laws, decisions, and related literature that can support primary data obtained through questionnaires. The sample is part of the number and characteristics possessed by the population. Sampling is needed if the population is enormous, and the researcher has limitations to cover the entire population. So the researcher needs 
to define the target population and the reachable population and then determine the number of samples and the sampling technique using the Slovin formula where:

$$
=\frac{n}{1+N e^{2}}
$$

\section{RESULT}

Research on the performance of home care-based health services and marine ambulance telemedicine in the city of Makassar. Service performance has an important role in carrying out this health service program, because health is very important for the community, so as to be able to improve the quality of health services to the community, especially the island community. [11] Public health has an important role in efforts to improve the quality of human resources, reduce poverty and economic development. The Human Development Index puts health as one of the main components of measurement apart from education and income. Therefore, every activity and effort to improve the health status of the community as high as possible is based on the principles of non-discrimination, participatory, protection, and sustainability which is very important for the formation of human resources. Indonesian human resources, increasing the nation's resilience and competitiveness, and national development

\subsection{Productivity}

Productivity is the ability of medical personnel and related agencies to carry out this marine ambulance home care and telemedicine program by providing services to island communities in need. [12]Associated with the effectiveness and efficiency of employees and related agencies' work to achieve the desired results.[13] This generally describes that the performance of home carebased health services and marine ambulance telemedicine in Makassar City has very good productivity with a percentage of $34.23 \%$ agreeing. Because the productivity of medical personnel who work in sea ambulances can improve health services to the island community and discipline in providing services to the community, and this also proves that the medical personnel on duty in the sea ambulance have sufficient skills to serve the island community who need first aid using this sea ambulance fleet service.

\subsection{Service Quality Service}

Quality is an essential component in a public Service, service quality is the service provided to the community by service standards that have been set in a policy. [14]Service quality tends to be very important in explaining the quality of public service performance. From service performance, there are also various public views about the satisfaction or dissatisfaction of the community when getting services by the relevant agencies.

This describes that in general, the performance of health services based on home care and marine ambulance telemedicine for service quality indicators is still not good, this can be seen from $33.8 \%$ or 104 people who answered that they did not agree. Because according to the people of the Barrang Lompo Islands, the existing equipment in the marine ambulance service is not sufficient, this is because most of the equipment is not functioning properly.

\subsection{Responsiveness}

This describes that in general, the performance of home care-based health services and marine ambulance telemedicine for responsiveness indicators is still not good, this can be seen from $32.6 \%$ or 100 people giving statements that do not agree. Because according to the people of the Barrang Lompo Island Archipelago, Makassar City, in obtaining this marine ambulance service, medical personnel are often not responsive enough to provide services. Often this marine ambulance suffers some damage, such as a malfunction in one of the engines which makes this marine ambulance service a mandate for a long period of time. So that it makes people who need the services of this marine ambulance fleet to be disturbed.

\subsection{Responsibility}

Responsibility explains whether the implementation of public organization activities is carried out in accordance with correct administrative principles or in accordance with organizational policies, both explicit and implicit. In the provision of services, there are various organizational administrative provisions and organizational principles that have been set to support the quality of employee responsibility for performance in service delivery.

This describes that in general the performance of home care-based health services and marine ambulance telemedicine for accountability indicators can be said to be good, this can be seen from $29.9 \%$ or 92 people giving statements agreeing to several sub-indicators of responsibility. This means that medical personnel or several parties 
related to this marine ambulance have provided services in accordance with the SOP or operational standards that have been set, one of which is not burdening the community with the costs of using this sea ambulance. And has provided services to the community in accordance with the principles of correct administrative standards.

\section{REFERENCES}

[1] Muñoz-Bonet JI, López-Prats JL, Flor-Macián EM, Cantavella T, Domínguez A, Vidal Y, et al. Medical complications in a telemedicine home care programme for paediatric ventilated patients. Journal of Telemedicine and Telecare 2020;26:462-73.

https://doi.org/10.1177/1357633X19843761.

[2] Michael M, Schaffer SD, Egan PL, Little BB, Pritchard PS. Improving Wait Times and Patient Satisfaction in Primary Care. Journal for Healthcare Quality 2013;35:50-61.

[3] Firdaus FF, Dewi A. Evaluasi Kualitas Pelayanan Terhadap Kepuasan Pasien Rawat Jalan Peserta Bpjs Di Rsud Panembahan Senopati Bantul 2018.

[4] Luthfia AR, Alkhajar Ens. Praktik Pelayanan Publik: Puskesmas Sebagai Garda Terdepan Pelayanan Kesehatan. Decision: Jurnal Administrasi Publik 2019;1:71. https://doi.org/10.23969/decision.v1i2.1802.

[5] Wahyu K, Wahyudi I. Kepuasan Pasien Terhadap Kualitas Pelayanan di Tempat Pendaftaran Pasien Rawat Jalan Puskesmas Kretek Bantul Yogyakarta. Jkesvo(Jurnal Kesehatan Vokasional 2017;2:140-8.

[6] Konli S. Pelayanan Kesehatan Masyarakat Di Puskesmas Desa Gunawan Kecamatan Sesayap Kabupaten Tana Tidung. EJournal Ilmu Pemerintahan 2014;2:1925-36.

[7] Calton B, Abedini N, Fratkin M. Telemedicine in the Time of Coronavirus. Journal of Pain and Symptom Management 2020;60:12-4. https://doi.org/10.1016/j.jpainsymman.2020.03. $\underline{019}$.

[8] Indira PH, Djazuly C. Customer Gappelayanan Bpjs Kesehatan Center. Urnal Administrasi Kesehatan Indonesia 2015;3:161-70.

[9] Andriani S, Sunarto. Kesehatan Rumah Sakit Umum Daerah Kabupaten Magelang. Kesehatan Kesehatan Masyarakat 2009;2:71-9.
[10] Arinkunto S. Prosedur Penelitian Suatu Pendekatan Praktik. JAKARTA: Rineka Cipta; 2006.

[11] Rahmqvist M. Patient satisfaction in relation to age, health status and other background factors: a model for comparisons of care units. vol. 13. 2001.

[12] Pollitt C. Performance management in practice: A comparative study of executive agencies. Journal of Public Administration Research and Theory 2006;16:25-44. https://doi.org/10.1093/jopart/mui045.

[13] Sienny T. Membangun Service Quality untuk Mencapai Kepuasan Konsumen di Industri Hospitality. Journals Management 2011;3:61-72.

[14] Utama A. Analisis Pengaruh Persepsi Kualitas Pelayanan Terhadap Kepuasan Pelanggan Rumah Sakit Umum Cakra Husada Klaten. Journal OPSI 2003;1:96110. 